\title{
The Green Image in the Spanish Hotel Sector: Analysis of Its Consequences from a Relational Perspective
}

\author{
José Ramón Sarmiento-Guede (D), Arta Antonovica and Rebeca Antolín-Prieto *(D) \\ Department of Business Economics, Rey Juan Carlos University, 28933 Madrid, Spain; \\ joseramon.sarmiento@urjc.es (J.R.S.-G.); arta.antonovica@urjc.es (A.A.) \\ * Correspondence: rebeca.antolin@urjc.es
}

Citation: Sarmiento-Guede, J.R.; Antonovica, A.; Antolín-Prieto, R. The Green Image in the Spanish Hotel Sector: Analysis of Its Consequences from a Relational Perspective. Sustainability 2021, 13, 4734 https://doi.org/10.3390/su13094734

Academic Editor: Brian Garrod

Received: 25 March 2021

Accepted: 21 April 2021

Published: 23 April 2021

Publisher's Note: MDPI stays neutral with regard to jurisdictional claims in published maps and institutional affiliations.

Copyright: (c) 2021 by the authors. Licensee MDPI, Basel, Switzerland. This article is an open access article distributed under the terms and conditions of the Creative Commons Attribution (CC BY) license (https:// creativecommons.org/licenses/by/ $4.0 /)$.

\begin{abstract}
The main objective of this research is to propose a hierarchy of effects model to study three antecedents of green brand image, such as trust, satisfaction and loyalty, and to examine the relationships between these variables. In this context, we investigated how these variables have been applied in the Spanish hotel management strategies for influencing consumer attitude and behavior. To test the proposed model empirically, personal surveys of 732 hotel customers were conducted in five Spanish cities using a structured questionnaire. A structural equations model was developed to test the research hypothesis. The main results indicate positive relationships between the green image and loyalty, the green image and satisfaction, the green image and trust. In addition, there are positive relationships between trust and loyalty, and finally between satisfaction and loyalty. From a practical point of view, hotel chains and their marketers must improve their green image through the correct design of activities, actions, and strategies to increase their clients' trust, satisfaction, and loyalty. In addition, the hotel chains must design green communication campaigns through their own and paid media to ensure that customers talk about them, and as a result, be able to influence the attitude and behavior of their customers. The results of our research provide a better understanding of the relationships between the green image, trust, satisfaction, and loyalty, following the framework of the hierarchy of effects model. By complementing previous studies on green image creation, this study offers an assessment of how green marketing strategies in the hotel industry increase trust, loyalty, and customer satisfaction.
\end{abstract}

Keywords: green image; green marketing; trust; satisfaction; loyalty; hierarchy of effects model; hospitality

\section{Introduction}

Of all the sectors that carry out a tourist activity in Spain, the hotel industry is not the one that has caused the greatest impact on the environment if we compare it with the holiday homes that consume the most of the land or different transport companies that are the most polluting. However, the hotel industry is one of the greatest generators of the tourist load. Therefore, comprehensive research studies are needed to analyze the impact it causes on the environment and how consumers perceive it [1].

Hotels are business organizations that consume large amounts of electricity, water, gas, and other disposable products in their daily activities, and all this has created a great threat to the environment in Spain [2]. Some authors like Valenzuela Rubio [1] affirm that hotel companies, no matter how green they are considered, will never be totally sustainable. Simultaneously, it does not prevent them from worrying about environmental sustainability, integrating different actions and strategies for improving the overall situation, and until it becomes a corporate value of these companies. Similarly, in recent years there has been a growing concern among consumers for environmental preservation and responsible consumption [3,4]. In this context, hotel consumers show a positive attitude towards green hotel practices, which motivates hotels to continue working to improve their environmental impact performance [5-7]. Hospitality companies and the industry, in general, should 
be aware of current sustainability trends and strive to orient their innovation operations towards more sustainability-oriented companies, as this will not only create a good image and reduce cost but also safeguard the natural attraction for the frequent guests $[8,9]$.

Green adjective not only applies to products, services, strategies and actions that have minimal impact on the environment, but they also are related to other aspects of sustainability and corporate social responsibility (CSR) in tourism sector [10]. Indeed, the green image can be understood as the perception consumers have in relation to the hotels' commitment to environmental protection [11]. Wang et al. [2] confirm that consumers, who perceive hotels as sustainable will change their attitude and behavior towards them, increasing satisfaction, loyalty and will generate positive content on the Internet with the intention to recommend green-friendly hotels to the people around them. Wu et al. [10] demonstrated that the quality of the brand and the eco-brand experience influence the satisfaction of the green brand experience. Also, Martínez [12] reveals that both trust and satisfaction have positive effects on loyalty. Mercade et al. [13] conclude that green marketing actions have a greater impact on their indirect relationship through word-ofmouth strategies, but direct relationship creates loyalty, which influences customer trust. Thus, understanding consumer attitudes and behavior towards environment conservation can help design green marketing strategies for hotel companies [14]. In this context, it permits us to justify this research paper from the practical implications point of view to reduce green brand skepticism. In addition, it can encourage to generate more effective green marketing strategies to augment the overall ecological image of the hotels and improve consumers' perception of them.

Taking into account these two previously mentioned situations: (1) the impact of the hotel sector on the environment and (2) the awareness of consumers towards responsible consumption, many Spanish hotels have begun to implement environmental programs within their corporate social responsibility (CSR) to create an image as green and sustainable hotel, which could be perceived as a competitive advantage in the market. In this sense, we propose the following research question (RQ):

\section{Does the Green Image of Hotels Influence the Spanish Customers?}

Concerning this research question, the main objective of this investigation is to analyze whether the green marketing strategies that are being implemented in the hotel sector have an influence on consumer attitudes and behavior. Specifically, this research aims to analyze the relationships and influence between the green image, satisfaction, trust and loyalty. From a relational perspective, satisfaction, trust and loyalty are considered essential constructs to develop a quality relationship.

Consequently, to achieve the proposed objective, we structure this research paper into four parts: (1) In the first part, we analyze previous studies related to the green image of the brand, trust, satisfaction and loyalty, and then we propose research hypotheses; (2) in the second, we explain the method used to verify the proposed hypotheses model; (3) in the third part, we present the main results and their discussion; (4) and in the last part, we expose the main conclusions, practical implications, limitations and possible future research.

\section{Theoretical Framework}

\subsection{Green Marketing}

Cohen and Murphy [15] indicate that in the mid-1960s ecological awareness emerged due to the consequences of uncontrolled consumption and its impact on the environment, but only during the 1980s [12], the term "green marketing" was used for the first time [16]. In the literature review, the concept of green marketing is often confused with terms, such as recyclable or environment, but as Polonsky [17] points out, green marketing can be understood as "all activities that produce a minimal impact on the environment and satisfy human needs or wishes". In addition, authors Do Paco et al. [18] highlight that green marketing is "the integral management process responsible for identifying, anticipating 
and satisfying the needs of customers and society in a profitable and sustainable manner". Therefore, green marketing does not only include those actions or strategies of organizations that increase the quality of life of the population, taking into account its satisfaction of their needs and wishes but also as an increase in the quality of the environment where they are located [19].

The main objective of green marketing for companies is to carry out realistic communication strategies and to eliminate communication actions based on isolated activities, which are far from a corporate strategy. All this pursues that companies internalize this concept for the future generational solidarity, and they are not using all the resources to satisfy their present needs [20]. How a company carries out its mission will make it gain or lose the credibility and social legitimacy necessary for its survival. This credibility, far from easy to achieve, requires the integration of a new corporate philosophy that consumers can be aware of their true commitment. After all, it is not about declaring countless ethical codes but co-create a climate and foster a business philosophy and ethics that permeates everything [21].

Ottman [22] indicates that green marketing should focus on providing benefits to consumers, and he proposes some goals in this sense:

- Ensure that the interest of consumers is focused on environmental issues related to the product or service they obtain;

- Make possible that consumers perceive that they are making a difference when purchasing this type of product or service;

- Make that consumers trust the company's values;

- Create the situation that customers prefer to consume these products rather than "non-green";

- Ensure that consumers understand the value of these products.

Therefore, Ottman [22] shows that if an organization can achieve the above five points through its green marketing strategies, it will be able to improve selling its products and services. Moreover, at the same time, it will increase performance and will become a potential source of innovation [22].

In the last decade, the hotel industry has understood that by meeting the requests of green consumers, it can provide the correct approach to the actions and activities of green marketing [13]. Since this sector consumes huge amounts of natural resources, water, and energy [23], many hotels use the label "green hotel" as a strategy to capture the attention of customers and to attract them [24]. The Green Hotels Association website [25] states that "green hotels are green properties whose managers are eager to implement programs that save water, energy and, while saving money, also reduce solid waste to help protect our planet".

Some investigations show that consumers are willing to pay a higher price for a product or service that is respectful to the environment and that also has a minimal impact on the environment [26,27]. In this context, the hotel sector more and more sees the opportunity to change consumer attitudes and behavior using green marketing strategies. Therefore, Table A1 (Appendix A) presents the most significant green marketing definitions.

In the existing literature, there are numerous investigations that analyze the relationship between the green image and loyalty in the hotel sector. For example, Martínez [12] developed a model of the antecedents of loyalty in the hotel sector. His represented results showed that the green image, satisfaction, and trust positively influence consumer loyalty in this sector. Similarly, Mercade et al. [13] researched the influence of green marketing strategies on satisfaction, loyalty and word of mouth communication in the hotel industry. The obtained results also proved that the correct development of green marketing strategies by hotels influences the development of word-of-mouth communication by consumers. But Wang et al. [2] investigated the relationship between the green image of the Chinese hotels and behavioral intention in Generation Y. The results showed that the relationship between the green image, satisfaction, trust, and behavioral intention in Generation $\mathrm{Y}$ are more significant than in the rest of the segments. Moreover, Foris et al. [28] analyzed the 
environmental practices that hotels carry out on booking websites and how customers perceive them. The results indicated that the hotel sector needs to provide more information on environmental practices and better use different communication tools [19].

In our research, by studying the relationship between the green image and loyalty, a conceptual model has been built on the hierarchy of effects model [29]. Specifically, the three dimensions of consumer behavior identified by Lavidge and Steiner [29] have been considered: (1) the cognitive dimension, which refers to the thoughts and beliefs of clients; (2) the affective dimension, which deals with emotions; and (3) the conative dimension, which encompasses the client's intentions and behaviors. Thus, this model allows us to describe the logical process that consumers can develop from their ignorance about the green image that hotels try to communicate, turning them into prescribers [13]. Martínez [12] affirms that the green image consists of a set of beliefs about the corporate image. Subsequently, these beliefs determine affective responses through confidence and green satisfaction due to the cognitive effort made by consumers. Moreover, finally, these affective responses influence the client's conative results, such as green loyalty. In summary, in the present research work, the green image in the hotel sector is considered as a cognitive dimension due to the intrinsic evaluations it causes in consumers. Trust and satisfaction are understood as affective dimensions due to the emotions that they trigger in customers, and finally, loyalty is considered as a conative dimension due to the intentions and behaviors of the consumers [5].

\subsection{The Green Image}

In recent years, much research has highlighted the importance of brand image and its influence on consumer behavior [12,29,30]. For Ogilvy [31], the brand image is "an essential work criterion in the brand communication process, since it shows that what lasts over time, is not so much a certain message associated with a concrete product, but it is a concrete projection in consumer beliefs, which is its mental representation". In this sense, Aaker [32] defines the brand image as "all existing associations in the minds of consumers". Specifically, he distinguishes three types of them, (1) functional associations related to physical products, brand symbols and other intangibles; (2) emotional or symbolic associations, such as the lifestyle perceived through the brand; and (3) associations related to one's own experience, such as memories of the use of the brand's products or services [33].

Taking as reference the definition of Ogilvy [31] and Aaker [32], the brand image can be understood as those perceptions that a consumer for a particular brand has and that is reflected in their associations and finally, that end up becoming the mental image of the brand when faced with a specific offer.

Based on the above statement and considering the different needs of consumers, Chen [16] developed a new concept of the green brand image, which he defined as "those perceptions of a brand that in the mind of the consumer appears linked to environmental concerns and commitments".

There are several investigations that confirm the influence of the brand image on consumer behavior [12,34]. Indeed, research by Folse et al. [35] demonstrated that brand image influences consumers' purchase intentions and their willingness to pay a higher price. Likewise, the study carried out by Schivinski and Dabrowski [36] tests the relationship between a brand and purchase intention. And in the context of the hotel sector, Wang et al. [2] argue that there is a positive relationship between the green brand image and the ecological intentions of behavior in terms of word of mouth communication, plan to visit it again and the willingness to pay a higher price for frequenting these types of establishments. Han et al. [37] have demonstrated in their research that there is a significant relationship between the green image of a cruise ship and the consumers' attitude toward them. However, the authors also indicated that this relationship influences less consumer behavior. Assaker, G. [3] affirms that there is a relationship between the green image of hotels and behavioral intentions, precisely, the intentions for developing word of mouth 
communication strategies or repeated purchases. In this context, we propose the first research hypothesis:

Hypothesis 1 (H1). The green brand image of hotels has a positive influence on customer loyalty.

\subsection{Satisfaction as a Consequence of the Green Image}

Satisfaction is considered a determinant for purchase intentions [5]. Especially, loyalty [38] that is based on consumer satisfaction is considered as an overall key factor leading to success in the hotel industry [39].

Oliver [40] defined satisfaction as the assessment that the consumer makes on features of the product or service and the pleasure moments it gives by consuming this product or service. This also includes the accomplishment of expectations previously created below or above the level.

Within the highly competitive hotel sector that offers homogeneous products and services, hotel managers must identify the needs of their customers and offer them services/products that stand out from the competition [9]. In this context, Chen [16] proposed a new concept called green satisfaction and defined it as "the pleasant level of consumption concerning meeting the environmental desires of consumers, their sustainable expectations and green needs". Along the same lines, Martínez [12] understands green satisfaction as "a level of feelings of pleasure that arises from the ability how product or service can satisfy needs, wishes and desires in a way that is environmentally rational, sustainable and ecological". This concept is based on the term satisfaction, but it is applied to the environmental context. In other words, it is understood as the satisfaction obtained through the fulfillment of expectations related to the environment, and this is the reason why this concept of green satisfaction also becomes a part of the total satisfaction of consumers.

In this context, several academics have considered that image plays a very relevant role in consumer satisfaction [33,34]. Thus, Chen's [16] research work confirmed the relationship between the green brand image and green satisfaction in the electronic products and services sector in Taiwan. Also, in the hotel sector, several articles were published that confirm the relationship between the green brand image and green satisfaction. For example, Martínez [12] raised and demonstrated the positive relationship between the general green image and satisfaction in a hotel environment following the framework of the hierarchy of effects model. One of the main contributions of this study is that it offers an evaluation of how the green marketing strategies applied by hotels can increase the green satisfaction level of consumers. Likewise, Wang et al. [2] developed a stimulus-organismresponse (S-O-R) model to verify the relationship between ecological image and green satisfaction in hotels in China within Generation $\mathrm{Y}$ as a moderating effect. The results showed that Generation $\mathrm{Y}$ is more aware of environmental aspects than other generations and that using green marketing strategies by hotels increases their level of satisfaction. In addition, Eid et al. [8] have demonstrated a significant relationship between the green image of Egyptian hotels and guest satisfaction. But Assaker et al. [41] have conducted a study using structural equations model applied to the luxury hotels' guests in London, and the results showed that the green image of hotels influences consumers satisfaction through the perception of quality.

Taking the previous studies as a basis and applying it to the ecological field, it can be established the following idea. There is a relationship between the fulfillment of the environmental wishes of consumers, their sustainable expectations and their green needs in associations of a particular brand. In this context, we propose the second hypothesis for this research work:

Hypothesis 2 (H2). The green brand image of hotels has a positive influence on customer satisfaction. 


\subsection{Trust as a Consequence of the Green Image}

The concept of trust has been studied in multiple disciplines, particularly in consumer behavior and marketing [2]. In this sense, Morgan and Hunt [42] understand trust as "the reliability and integrity of the relationship in exchange". According to this definition, trust seems to be understood not only as a cognitive dimension but also as an affective dimension, which is essential for any type of relationship and, in particular, for the relationship models that develop within the discipline of marketing [43].

Although Chen [16] considered green trust as a desire and ability related to the environment and concerning this, he wrote that "the desire to depend on a product, service, or brand is based on the belief or expectation resulting from its credibility, benevolence, and ability regarding their environmental performance". Martínez [14] also defined green trust as "the willingness to depend on an exchange partner in which one has trust due to its environmental performance". However, Portillo and Esteban [44] affirm that many consumers do not trust the environment-based arguments of brands. Consequently, efforts to have a good image in the environmental field are valued by consumers, and it is necessary to create a bond of trust with them through good positioning related to the environment and promotional activities to support it [45].

In the hotel sector, customer trust is positively influenced by brand image since trust can reduce the risk perceived by customers while increasing the probability of purchase [12,34,46,47]. Similarly, as Martínez [12] argues, the more favorable green image is the greater trust customer places in a brand due to the sentiment generated by the level of care that the organization shows about its environmental commitment. Thus, Chen [16] stated that it was possible to apply the existing relationship between brand image and trust in the ecological sphere, and therefore, the influence that a brand may have on concerns and environmental commitments of consumers also are evaluable. Also, Wang et al. [2] have conducted research in the hotel sector and applied the stimulus-organism-response (S-O$\mathrm{R})$ model to the millennial segment. The results indicated that there is a strong relationship between the green image of the hotels and the guests' satisfaction and trust. Bashir et al. [5] state that the more positive the hotel's green image is, the more trust customers will place in them. In this context, we propose the following third hypothesis:

Hypothesis 3 (H3). The green brand image of hotels has a positive influence on the customers' trust.

\subsection{Loyalty as a Consequence of the Green Image}

Loyalty is considered as one of the most important terms to explain how the consumer chooses between the different brand options. Therefore, this concept has aroused great interest among academics and marketing professionals [41,48]. In this context, we can define loyalty as an attitude that is understood as the customer's psychological commitment towards a product, service or brand according to his experience [49]. Or we can define it as a repeated purchase behavior of the same brand $[13,50]$. The problem with understanding loyalty in terms of behavior is that there can be many situations in which consumers do not buy the services or products again of the same hotel due to comfort concerns, lack of income, multiple available options, etc. However, the definitions of loyalty seem to revolve around purchasing behavior accompanied by a favorable attitude [3,43].

Consequently, loyalty to the green image can be understood as repurchase intentions of consumers and the positive attitude towards organizations with an environmental and sustainable commitment over time. However, there may be two situations: the first, that consumers are only loyal to a company because they do not have any other alternative, or the second occurs when consumers prefer a company regardless of existing competitors. On the basis of the last option, hotels must take advantage of this competitive lead and include green products into their environmental strategies. Indeed, Morgan and Hunt [42] were the first to show that trust helps stimulate exchanges between partners. It also serves as a breakpoint on short-term alternatives in favor of the expected long-term benefits to keep up with the current members. Assaker et al. [41] indicate that trust reduces uncertainty 
in settings where consumers feel vulnerable. Today, it is vitally important for brands to gain the trust of the consumer to forge their loyalty and to reduce the risk in exchange relations. There are numerous studies that have proven the positive relationship between trust and loyalty in the hotel sector [5,12,13,51]. Moreover, Bashir et al. [5] carried out research work in hotels in Malaysia and showed that when the confidence of the guests towards the green image of the hotel increases, so does the loyalty, and there is a relationship between these two concepts. Also, Assaker et al. [41] demonstrated in a study conducted in luxury hotels in Europe that trust is a mediator between the green image of a hotel and customer loyalty. Therefore, we propose the following research hypothesis:

Hypothesis 4 (H4). Customers' trust has a positive influence on customer loyalty.

Oliver [40] has stated that satisfaction was a prerequisite to loyalty and identified up to six associations between these concepts, but one that best describes it is the one, which indicates that satisfaction does not transform into loyalty, but rather that, at most, satisfaction is a seed that requires daily nourishment so that loyalty can sprout. In the same way, Oliver [40], Sarmiento and Ferrao [43] argue that clients begin to develop levels of loyalty when they are satisfied with the performance of the organization. Thus, Martínez [7] affirms that there is a relationship between satisfaction and loyalty in the hotel sector. In addition, he adds that customers will develop loyalty levels towards a hotel when they are satisfied with the service or the hotel's image.

Assaker, G. [3], in his work, confirms that green organizations that meet the needs of their customers better than major competitors will find it easier to develop levels of green loyalty. Assaker et al. [41] also confirm the relationship between satisfaction and loyalty. Specifically, they state that satisfaction influences not only customer retention but also their purchase intention. Considering these statements and focusing on the implementation of this relationship, we propose the fifth hypothesis:

Hypothesis 5 (H5). Customers' satisfaction has a positive influence on customer loyalty.

\section{Methodology}

\subsection{Sample Participants}

In the present study, the survey method and the structured questionnaire tool were used to collect data from the sample and to test the hypotheses previously created. The sample consisted of clients of ecological hotels who had previously used this type of establishment. A convenience sample was applied to ensure greater representativeness of the data. Specifically, in this research work, a multi-stage sampling was employed by quotas based on the sex and age of the hotel customers [2].

The questionnaire was carried out in the five most touristic cities in Spain according to the latest INE report [52] on the hotel occupancy of national and international tourists in 2019. These cities were Madrid (9,963,195 tourists), Barcelona (8,520,415 tourists), Sevilla (2,811,351 tourists), Palma de Mallorca (2,372,933 tourists) and Benidorm (2,150,417 tourists). The geographical situation of these cities can be found in Figure A1 (Appendix B). Once the cities had been selected, it was decided to ask for the collaboration of the hotels that appeared on the TripAdvisor search engine with the ecological label. The collaboration of 135 hotels was sought, but only 20 hotels were approved. The chi-squared test was used to prove that there were no significant differences in the collected data from these studied cities [2].

In total, there were distributed 1500 questionnaires, and 867 were returned. One hundred thirty-five of them were discarded as incomplete. Thus, 732 questionnaires were finally considered valid. This assumes a response rate of $48.8 \%$. Table 1 shows the profile of the respondents in which gender, education, income level, age and nationality are represented. 
Table 1. Profile of respondents.

\begin{tabular}{cccc}
\hline Item & Classification & Number of Responses & \% \\
\hline \multirow{2}{*}{ Gender } & Male & 382 & 52.18 \\
& Female & 350 & 47.82 \\
Education & Master or doctorate & 280 & 38.26 \\
& Bachelor's degree & 352 & 48.08 \\
& Secondary education & 100 & 13.66 \\
Income & Medium-high & 139 & 20.5 \\
& Medium & 465 & 64.25 \\
& Medium-low & 108 & 15.25 \\
Age & Less than 20 & 115 & 15.73 \\
& Between 21 and 29 & 169 & 23.08 \\
& Between 30 and 39 & 178 & 24.31 \\
& Between 40 and 49 & 147 & 20.08 \\
& More than 50 & 123 & 16.80 \\
Nationality & Spanish & 685 & 93.57 \\
& Other countries & 47 & 6.43 \\
\hline
\end{tabular}

Source: own elaboration.

\subsection{Instruments}

The questionnaire has been designed by various factors based on the available literature to measure the influence of the green image on the consumers' attitudes and behavior. Indeed, the factors that make up this instrument are the green image $[2,12,13]$, trust $[2,12,13]$, satisfaction $[2,12]$, and loyalty $[12,13]$. The measurement items used in this study are presented in Table A2 (Appendix C).

The questionnaire consisted of 22 questions. The first two were filter questions to give greater validity to our research work. The following sixteen questions were made up of scale-type questions related to the measurement factors (green image, trust, satisfaction and loyalty), and the last four questions were connected to the sociodemographic situation of the respondents. All responses were based on a Likert scale with the minimum value 1 (totally disagree) and the maximum value 7 (totally agree). The questionnaire layout also included an introduction section, which consisted of a short introduction explaining the procedure for completing it and the main purpose of the research project.

\subsection{Research Field Process}

The questionnaire was applied at the main entrance of the studied hotels and was carried out between 15 June and 25 July 2020, considering that these are the dates with the highest influx of tourists, and in different hours to know the perceptions of all the profiles of customers, who stayed in each studied hotel. To comply with the health and safety measures against COVID-19 in Spain, all the survey participants were given the questionnaire in open envelopes and disinfectant gel. Once the questionnaire was completed, it was returned in the same closed envelope. The duration of data collection took approximately 15 min per respondent.

\subsection{Data Processing}

The Statistical Package for the Social Sciences (SPSS Version 25) was applied for the analysis and treatment of the data. This software was used for the analysis of the distribution of frequencies, averages and dispersion measures, but the SPSS Amos 25.0 in the interpretation of the structural analysis. Reliability analysis was also carried out to confirm the internal consistency of the scales using the statistical calculation of Cronbach's alpha. Finally, a confirmatory factor analysis (CFA) was employed to check the model's validity using the EQS structural equations program. 


\section{Results}

We employed Cronbach's alpha $(\alpha)$, composite reliability index (CRI) and average variance extracted (AVE) to know internal consistency obtained from the scale responses used in the questionnaire.

As it can be seen in Table A3 (Appendix D), Cronbach's alpha values are generally favorable and offer good internal consistency in four scales since they exceed the cutoff point of 0.70 suggested by Hair et al. [47]. Specifically, the green image obtained a value of 0.83 ; trust 0.86 ; satisfaction 0.91 ; and loyalty 0.86 . Regarding the composite reliability (CF), we can observe that the values of the four scales are comprised above 0.70 , and this value is supported by Hair et al. [53]. Therefore, the reliability of the used scales in the instrument is approved. The average variance extracted (AVE) of the scales was also analyzed, and it was confirmed as values which are greater than 0.50 [53].

Table A3 (Appendix D) similarly shows the results of the confirmatory factor analysis (CFA). These results indicate a good fit for the model. Specifically, the root-mean-square error of approximation (RMSEA) obtains a correct adjustment value of 0.078 , thus, below the value of 0.08 recommended by Hair et al. [53]. The rest of the values, such as the comparative fit index $(\mathrm{CFI}=0.943)$, the non-normalized adjustment index $(\mathrm{NNFI}=0.923)$ and the incremental adjustment index $(\mathrm{IFI}=0.975)$, give us values above 0.90 , which also are recommended by Hair et al. [53].

Table 2 illustrates the discriminant validity that measures how a certain dimension is different from the rest. As can be observed, none of the confidence values contain the value 1, as indicated by Fornell and Larcker [54]. Thus, we can conclude that the scales used in the model have adequate reliability and validity.

Table 2. Results of discriminant validity.

\begin{tabular}{ccccc}
\hline & $\mathbf{1}$ & $\mathbf{2}$ & $\mathbf{3}$ & $\mathbf{4}$ \\
\hline 1 Green image & 0.783 & & & \\
2 Trust & 0.446 & 0.813 & & \\
3 Satisfaction & 0.596 & 0.445 & 0.667 & 0.768 \\
4 Loyalty & 0.584 & 0.612 & 0.661 & \\
\hline
\end{tabular}

Note: Diagonal items in bold are the square root of the shared variance between the scales and their measures. Items off the diagonal are the correlations between the scales. Source: own elaboration.

Table 3 demonstrates the results of the structural equation model using the maximumlikelihood method [53]. In this sense, we can observe a positive relationship between the green image and loyalty of the hotel customers in Spain $(\beta=0.202 * ; p<0.05)$. Thus, the null hypothesis is rejected, and hypothesis 1 is supported. Moreover, the model shows a positive relationship between the green image and satisfaction $\left(\beta=0.216^{*} ; p<0.05\right)$, which legitimizes us to reject the null hypothesis and to accept hypothesis 2 . The results also showed that the green image is significant in customers' trust $\left(\beta=0.623^{*} ; p<0.05\right)$, and hypothesis 3 is also supported. Hypothesis 4 of the relationship between trust and loyalty is approved with the results $\left(\beta=0.636^{*} ; p<0.05\right)$. Finally, it can be observed that there is a positive relationship between satisfaction and loyalty $(\beta=0.364 * ; p<0.05)$, thus, the null hypothesis is rejected, and hypothesis 5 is supported. The $p$-value for the proposed model was less than 0.05 , which indicates that the raised hypotheses can be accepted and that at least some of the parameters are different from zero. Consequently, the model is valid.

Regarding indirect relationships, we can affirm that the green image has a positive effect on loyalty through trust $\left(\beta=0.236^{*} ; p<0.05\right)$ and through satisfaction $\left(\beta=0.268^{*}\right.$; $p<0.05)$. The sum of the indirect effects $(0.504)$ determine a low significant relationship.

In addition, the results uncovered that the green image supports $84 \%$ of trust $\left(\mathrm{R}^{2}=0.84\right)$ and $81 \%$ of satisfaction $\left(\mathrm{R}^{2}=0.81\right)$. The green image, trust and satisfaction support loyalty by $76 \%\left(R^{2}=0.76\right)$. Subsequently, trust, satisfaction and loyalty can be considered as substantial variables. In Figure 1, it can be observed that the results of the trajectory coefficients from the green image to satisfaction, trust and loyalty were all statistically 
significant and in the expected directions. In the same way, the trajectory coefficients from trust and satisfaction to loyalty were also the same.

Table 3. Results of discriminant validity.

\begin{tabular}{ccccc}
\hline Hypothesis & Structural Relationship & B Standardizations & Value & Criterion \\
\hline H1 & Green image-Loyalty & $0.202^{*}$ & 2.983 & Accepted \\
H2 & Green image-Satisfaction & $0.216^{*}$ & 2.876 & Accepted \\
H3 & Green image-Trust & $0.623^{*}$ & 11.132 & Accepted \\
H4 & Trust-Loyalty & $0.636^{*}$ & 6.354 & Accepted \\
H5 & Satisfaction-Loyalty & $0.364^{*}$ & 4.491 & Accepted \\
\hline
\end{tabular}

Source: own elaboration. Note. $\mathrm{N}=732 ;{ }^{*} p<0.05 ; \times 2=417.364 ; \mathrm{df}=115(p=0.000) ; \mathrm{NNFI}=0.923 ; \mathrm{CFI}=0.943$ $\mathrm{IFI}=0.975 ;$ RMSA $=0.078$.

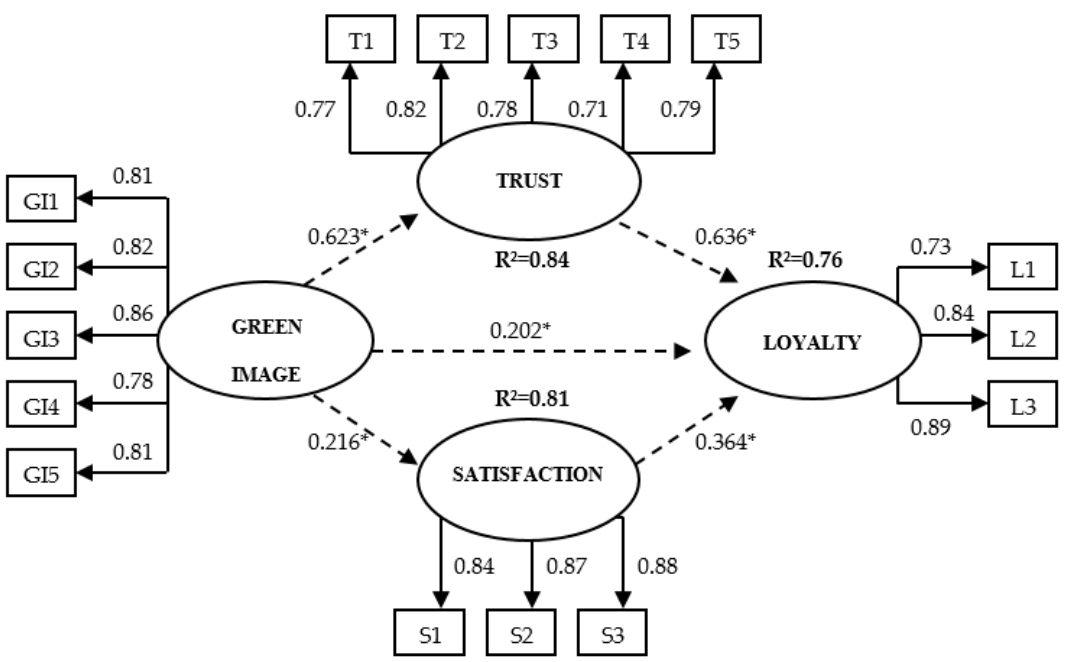

Figure 1. Research model proposal. Source: own elaboration.

\section{Discussion}

All results presented in the previous section confirm that there is a direct relationship between the green brand image, trust, satisfaction and loyalty, as argued by Martinez [12] Assaker et al. [41], Bashir et al. [5], and Assaker, G. [3,34]. Other works, such as Wang et al. [2] and Mercade et al. [13], only used green word of mouth communication instead of green loyalty. The choice of trust, satisfaction and loyalty, as a consequence of the green image, is because, in a review of the available literature, it has been shown that these are dimensions which the best explain customers attitudes and behavior, and also they correspond with the main objective of this research [8,37]. This type of study is especially relevant for the Spanish hotel industry when there are used different communication tools to "sell" a green image by influencing its customers and increase the level of trust, satisfaction and loyalty. As Martínez [7] and Assaker [3] argue, the success of tourism organizations is not only measured by the increase of their profitability but also by the attitude and behavior of their clients towards the brand image.

The results show that for the verification of the relationship between the green brand image, trust, satisfaction and loyalty [13], the hierarchy of effects model is the best that can explain these relationships. In addition, it demonstrates causal relationships, and it is the best-suited model that analyses customer behavior through three dimensions, such as cognitive, which would be related to the green image; the affective one that would be related to trust and satisfaction; and finally, the conative that would be related to loyalty. Therefore, this model can describe the logical process consumer develops from his ignorance of the green image that hotels try to change to become loyal customer [2]. Unlike other research, our model provides the results of the $\mathrm{R}^{2}$ and confirms that our model fits with the provided data [55] 
The results also show that for influencing the behavior of hotel customers and achieve their loyalty, there are two ways to do this [41]. The first one is by generating green content to change the beliefs and thoughts of customers, as demonstrates H1. Moreover, the second way is by creating green content to develop emotions and feelings through trust and satisfaction, as have been supported by H2, H3, H4 and H5 [5].

The obtained results reveal that customer concerns about the environment and responsible consumption are a reality $[4,28]$. Hotel chains must not only develop actions and strategies aimed at preserving the environment but also must convert it into a corporate value. In addition, the results show that a correct communication of these corporate values generates a positive customer attitude that is formed through trust and satisfaction towards the brand [13,41]. Similarly, positive recommendations in offline and online environments, as well as a behavior of repeat purchase, can change consumer behavior towards loyalty $[50,56]$.

All the proposed hypotheses have been supported, and they show a positive relationship between the green image of hotels and satisfaction, trust and loyalty. The acceptance of all the hypotheses was also presented in the research papers as Martínez [12], Wang et al. [2], Mercade Mele et al. [13] and Bashir et al. [5].

\subsection{Practical Implications}

This research provides relevant academic and practical implications. From the academic implications point of view, it should be noted the following aspects. First, the literature review from a relational and green marketing approach has been carried out to develop a model that could answer the raised research question, and it was referred to how the green image of the Spanish hotel chains influences the attitude and behavior of their customers. However, this work provides more concrete definitions of green brand image, trust, satisfaction and loyalty. Second, most of the research studies in the tourism and hotel sector do not include green marketing in their research models, which contradicts the current concerns of consumers. In this context, this scientific paper fills in this research gap and offers a solid theoretical foundation on green marketing. Third, this work provides empirical evidence on the role of trust and satisfaction in developing loyalty, and in this sense, it is consistent with other previous research. It also offers a better-structured methodology with more significant results.

From the practical implications point of view, depending on the strategic plans of each hotel or Spanish tourism organization, the green image can be improved through the correct design of activities, actions and strategies to increase trust, satisfaction and loyalty of its clients. First, to achieve good results, hotel chains should use local or nearby raised biological food that is labeled with adequate certifications. In this way, by reducing using chemical products and transport mobility, $\mathrm{CO}_{2}$ emissions would be decreased. Similarly, the activity that pollutes the most is cleaning. The best way to reduce its impact would be by using ecological and biodegradable products. Another activity could be developed for water and electricity saving. For this, some hotels are employing low-consumption light bulbs, install solar panels and water flow reducers, or reuse of rainwater. Second, in the restaurant section could be offered vegetarian or vegan products. In addition, using plastic for serving food products should be abandoned and glass containers promoted. In the hotel rooms should appear signs that inform clients on turning off the light when they are leaving the room, the paper they use is recycled, and the furniture in the room is produced from the recycled or sustainable materials. Third, hotels must rethink the way they transfer their customers. For this reason, hotels should promote public transportation use or give the possibility of recharging electric cars in their facilities or provide bicycle and electric scooter services. This type of activities and actions should be developed by all types of hotels, from medium category to luxury hotels. For example, Meliá hotels have decided to eliminate all the plastic from their establishments. In addition, $\mathrm{NH}$ hotels and Vinci Hotels have opted to abolish using any kind of chemical products. 
All these activities and actions that we have described previously will not make any sense if hotel chains do not communicate them through their corporate media, as we have proved that the green image influences customer satisfaction, trust and loyalty. To do so, the hotel chains, which want to transmit their image based on environmental aspects, should actively participate in forums, ecological events and increase their online presence on social media, such as Facebook, Twitter, Instagram, or YouTube. In addition, the hotel chains must design ecological communication campaigns through their own and paid media to ensure that customers talk about them, and as a result, hotels will be able to influence the attitudes and behavior of their customers. The brand image of a hotel chain is made up of the logo, the slogan, the colors, and other typography. Hence, hotel chains must relate their visual identity strategy with environmental aspects in order to correctly transmit their green image.

Another aspect from a relational and green marketing perspective, it is important to understand that hotel chains not only must target their end customers, but also they must direct communication strategies towards their employees through using internal communication tools (for example, internal magazines, Intranet, corporate posters in establishments or internal social media). Employees are a fundamental pillar to transmit information to customers. Hence, it is vital that they know the company's strategy related to the environmental implications.

Likewise, DMOs should support and promote the efforts made by tourism companies to create a green brand image. This requires that DMOs stop being only a source of information but also become active participants that develop relationships and collaborate with all interested parties, such as tourists, residents, non-governmental associations and tourism professionals, to create a local ecotourism brand. Green hotels should rely on DEMOs to make stakeholders aware of the importance of sustainability. Hence, in Figure A2 (Appendix D), it can be observed how different stakeholders, including DMOs, can influence the creation of the green brand image of a tourism destination.

\subsection{Research Limitations}

There are several limitations of this research. First, the fieldwork was developed in June and July of 2020, when tourist mobility and hotel management were affected by the COVID-19 pandemic. Therefore, we have received many negative responses for collaboration from different hotels because most of them were partially or completely closed. This situation influenced the final sample size. Second, the study was applied to the guests who stayed in the five most visited cities in Spain. Thus, there could be different results concerning studied variables applied in different countries all around the world. Third, most of the surveyed guests were of Spanish nationality. As a result, the green image variable relationships could have distinct results for other nationalities. Finally, and as the last limitation, other variables that influence the creation of the green image for the hotel industry could be studied.

\subsection{Future Research Directions}

For future research, we have identified four interest lines. First, the presented model could be applied to other tourism sectors, such as restaurants, transportation or the leisure industry. Second, it would be interesting to apply this model in other countries with different cultures to see the main differences. Third, other affective dimensions, such as commitment or conative dimensions, word of mouth communication could also be used. Finally, gender or age could be analyzed as moderator variables to check if there are significant differences.

Author Contributions: J.R.S.-G., A.A., and R.A.-P. conceived and designed the editorial; J.R.S.-G., A.A., and R.A.-P. analyzed the re-sults and wrote the paper. All authors have read and agreed to the published version of the manuscript.

Funding: This research received no external funding. 
Institutional Review Board Statement: Not applicable.

Informed Consent Statement: Not applicable.

Data Availability Statement: Not applicable.

Conflicts of Interest: The authors declare no conflict of interest.

\section{Appendix A}

Table A1. Green marketing definitions.

\begin{tabular}{|c|c|}
\hline Reference & Definition \\
\hline Polonsky [17] & $\begin{array}{l}\text { The green marketing can be understood as "all activities that produce a minimal impact on the } \\
\text { environment and satisfy human needs or wishes". }\end{array}$ \\
\hline Fuller [57] & $\begin{array}{l}\text { Green marketing is the process of planning, implementation and control of the development, pricing, } \\
\text { communication and distribution of products to achieve the objectives proposed by each company to } \\
\text { meet the needs of consumers and to develop a harmonizable procedure with the environment. }\end{array}$ \\
\hline Calomarde [58] & $\begin{array}{l}\text { Green Marketing is responsible for transmitting to humanity the practice of the culture of permanence. } \\
\text { That is the function of protecting the natural environment for the future. }\end{array}$ \\
\hline Ottman et al. [56] & Green marketing aims to satisfy the needs of consumers and favor environmental conditions. \\
\hline Do Paco et al. [18] & $\begin{array}{l}\text { Green marketing is the integral management process responsible for identifying, anticipating, and } \\
\text { satisfying in a profitable and sustainable way the needs of customers and society. }\end{array}$ \\
\hline $\begin{array}{l}\text { American Marketing } \\
\text { Association [59] }\end{array}$ & $\begin{array}{l}\text { "Green marketing refers to the development and marketing of products, designed to minimize negative } \\
\text { effects on the physical environment or to improve their quality". This definition is also used to express } \\
\text { the work involved, for example, making a product according to the ecological thinking of each consumer. }\end{array}$ \\
\hline
\end{tabular}

\section{Appendix B}

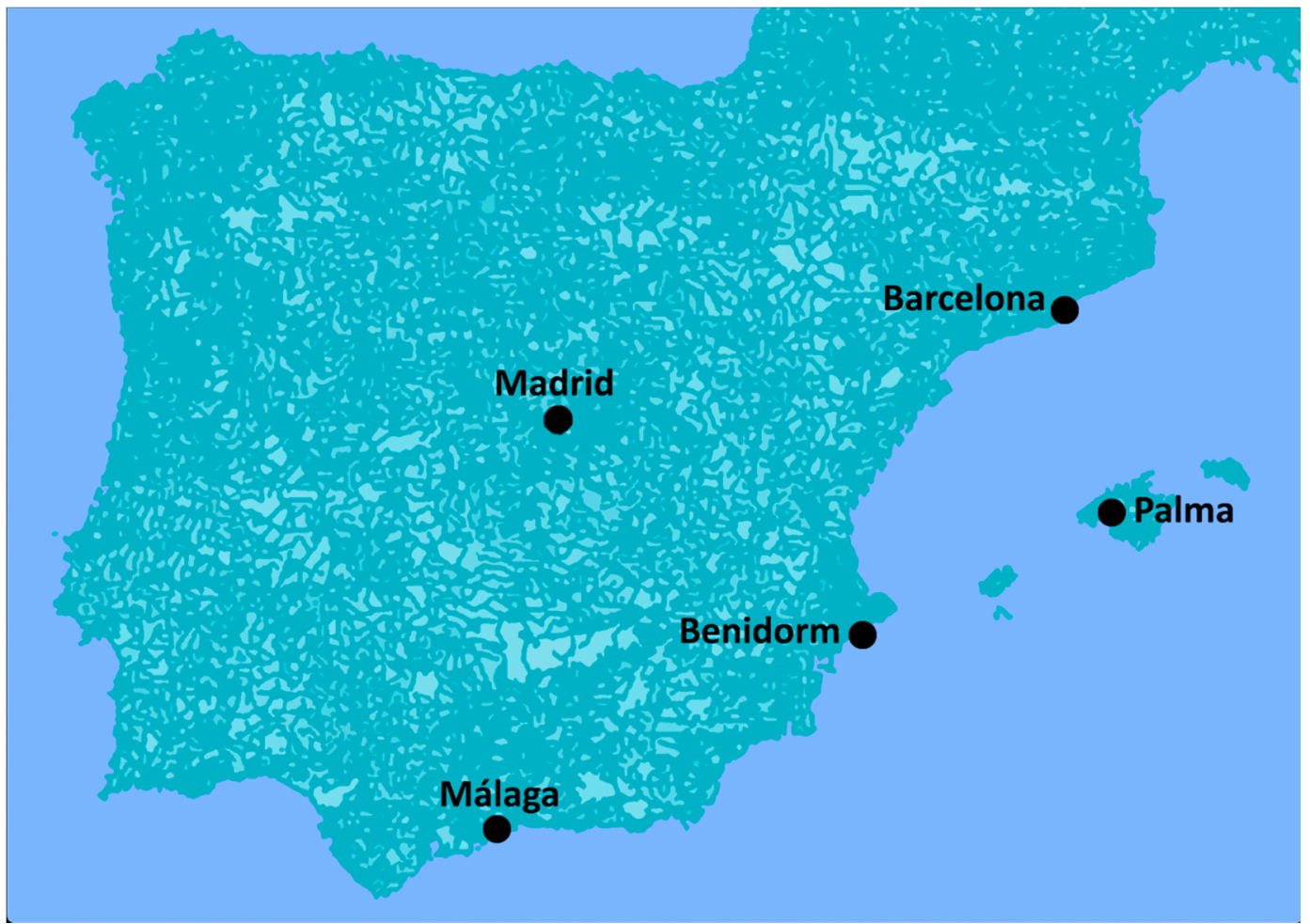

Figure A1. Location of the cities. Source: own elaboration. 


\section{Appendix C}

Table A2. Structure of the confirmatory factor analysis.

\begin{tabular}{|c|c|c|}
\hline Factor & Items & Reference \\
\hline Green image & $\begin{array}{l}\text { GI1: This hotel seems to be environmentally responsible } \\
\text { GI2: This hotel is a landmark in environmental policies } \\
\text { GI3: This hotel has a good ecological image } \\
\text { GI4: This hotel protects the environment } \\
\text { GI5: This hotel would reduce its income to protect the environment }\end{array}$ & $\begin{array}{l}\text { Martínez [12]; Wang et al. [2]; } \\
\text { Mercade et al. [13]; } \\
\text { Assaker et al. [41]; } \\
\text { Bashir et al. [5]. }\end{array}$ \\
\hline Trust & $\begin{array}{l}\text { T1: The environmental commitments of this hotel are reliable } \\
\text { T2: The environmental concerns of this hotel meet my expectations } \\
\text { T3: This hotel is honest with its environmental concerns } \\
\text { T4: The environmental policy of this hotel is reliable } \\
\text { T5: The environmental communication of this hotel is reliable }\end{array}$ & $\begin{array}{l}\text { Martínez [12]; Wang et al. [2]; } \\
\text { Mercade et al. [13]; } \\
\text { Assaker et al. [41]; } \\
\text { Bashir et al. [5]. }\end{array}$ \\
\hline Satisfaction & $\begin{array}{l}\text { S1: The environmental commitment of this hotel meets my needs } \\
\text { S2: The environmental policy of this hotel meets my needs } \\
\text { S3: The environmental values that this hotel transmits satisfy my needs } \\
\text { L1: Generally, I choose this hotel as the first option }\end{array}$ & $\begin{array}{c}\text { Martínez [12]; Wang et al. [2]; } \\
\text { Assaker et al. [41]; Bashir et al. [5]. }\end{array}$ \\
\hline Loyalty & $\begin{array}{l}\text { L2: I would make positive comments about this hotel to my friends and } \\
\text { through social media } \\
\text { L3: I would choose this hotel even if the competitors had the same attributes }\end{array}$ & $\begin{array}{l}\text { Martínez [12]; Mercade et al. [13]; } \\
\text { Assaker et al. [41]; Bashir et al. [5]. }\end{array}$ \\
\hline
\end{tabular}

Source: own elaboration

Table A3. Confirmatory factor analysis.

\begin{tabular}{|c|c|c|c|c|c|}
\hline Factor & Items & $\begin{array}{c}\text { Standard } \\
\text { Lambda Loads }\end{array}$ & $\alpha$ & AVE & CRI \\
\hline Green image & GI1: This hotel seems to be environmentally responsible & 0813 & & & \\
\hline Martínez [12]; & GI2: This hotel is a landmark in environmental policies & 0.813 & & & \\
\hline Wang et al. [2]; & GI3: This hotel has a good ecological image & 0.8 & & & \\
\hline Mercade et al. [13]; & GI4: This hotel protects the environment & $\begin{array}{l}0.865 \\
0780\end{array}$ & 0.834 & 0.789 & 0.823 \\
\hline $\begin{array}{l}\text { Assaker et al. [41]; } \\
\text { Bashir et al. [5]. }\end{array}$ & $\begin{array}{l}\text { GI5: This hotel would reduce its income to protect } \\
\text { the environment }\end{array}$ & $\begin{array}{l}0.789 \\
0.813\end{array}$ & & & \\
\hline Trust & T1: The environmental commitments of this hotel are reliable & 07 & & & \\
\hline Martínez [12]; & T2: The environmental concerns of this hotel meet my expectations & 0.823 & & & \\
\hline Wang et al. [2]; & $\begin{array}{l}\text { 12: The environmental concerns of this hotel meet my expectations } \\
\text { T3: This hotel is honest with its environmental concerns }\end{array}$ & 0.023 & 0.865 & & \\
\hline Mercade et al. [13]; & 13: Inis hotel is honest with its environmental concerns & 0.781 & 0.865 & 0.645 & 0.782 \\
\hline Assaker et al. [41]; & $\begin{array}{l}\text { 14: The environmental policy of this hotel is reliable } \\
\text { T5: The environmental communication of this hotel is reliable }\end{array}$ & $\begin{array}{l}0.715 \\
0798\end{array}$ & & & \\
\hline Bashir et al. [5]. & 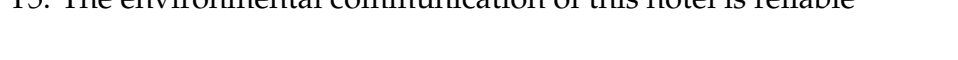 & & & & \\
\hline $\begin{array}{l}\text { Satisiaction } \\
\text { Martínez [12]; }\end{array}$ & S1: The environmental commitment of this hotel meets my needs & 0.845 & & & \\
\hline Wang et al. [2]; & S2: The environmental policy of this hotel meets my needs & 0.872 & 0.913 & 0.765 & 0.782 \\
\hline $\begin{array}{l}\text { Assaker et al. [41]; } \\
\text { Bashir et al. [5]. }\end{array}$ & $\begin{array}{l}\text { S3: Ine environmental values that this notel transmits satisfy } \\
\text { my needs }\end{array}$ & 0.883 & & & \\
\hline Loyalty & L1: Generally, I choose this hotel as the first option & & & & \\
\hline Martínez [12]; & L2: I would make positive comments about this hotel to my & 0.734 & & & \\
\hline Mercade et al. [13]; & friends and through social media & 0.845 & 0.865 & 0.673 & 0.734 \\
\hline $\begin{array}{l}\text { Assaker et al. [41]; } \\
\text { Bashir et al. [5]. }\end{array}$ & $\begin{array}{l}\text { L3: I would choose this hotel even if the competitors had the } \\
\text { same attributes }\end{array}$ & 0.89 & & & \\
\hline \multicolumn{6}{|c|}{ Goodness of fit } \\
\hline \multicolumn{6}{|c|}{$\begin{aligned} & \left.x^{2} \text { (g. } 1 .\right)=246.27 ; \mathrm{df}=115(p=0.000) \\
\mathrm{NNFI}= & 0.923 ; \mathrm{CFI}=0.943 ; \mathrm{IFI}=0.975 ; \mathrm{RMSA}=0.078\end{aligned}$} \\
\hline
\end{tabular}

Source: own elaboration. Note: $(\alpha)$ : Cronbach's alpha; AVE: average variance extracted; CRI: composite reliability index; RMSEA: root-mean-square error of approximation; (CFI) comparative fit index; (NNFI): The non-normed fit index; (IFI): incremental fit index. 


\section{Appendix D}

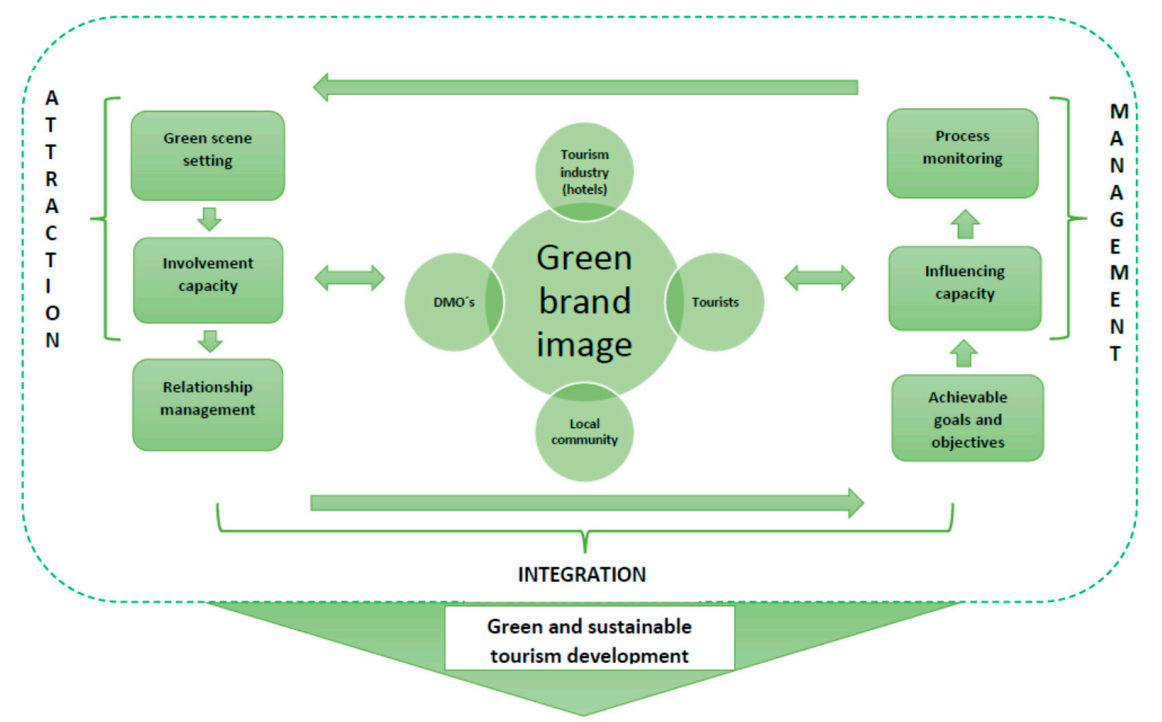

Figure A2. Multi-stakeholder involvement in green brand image creation Source: own elaboration adapted from Feyers et al., 2020.

\section{References}

1. Valenzuela Rubio, M. La sostenibilidad ambiental del sector hotelero español. Una contribución al turismo sostenible entre el interés empresarial y el compromiso ambiental. Arbor 2017, 193. [CrossRef]

2. Wang, J.; Wang, S.; Xue, H.; Wang, Y.; Li, J. Green image and consumers' word-of-mouth intention in the green hotel industry: The moderating effect of Millennials. J. Clean. Prod. 2018, 181, 426-436. [CrossRef]

3. Assaker, G. The effects of hotel green business practices on consumers' loyalty intentions: An expanded multidimensional service model in the upscale segment. Int. J. Contemp. Hosp. Manag. Int. 2020, 32, 3787-3807. [CrossRef]

4. Juvan, E.; Dolnicar, S. Drivers of pro-environmental tourist behaviours are not universal. J. Clean. Prod. 2017, 166, 879-890. [CrossRef]

5. $\quad$ Bashir, S.; Khwaja, M.G.; Rashid, Y.; Turi, J.A.; Waheed, T. Green Brand Benefits and Brand Outcomes: The Mediating Role of Green Brand Image. Sage Open 2020, 10. [CrossRef]

6. Fuentes-Moraleda, L.; Lafuente-Ibáñez, C.; Muñoz-Mazón, A.; Villacé-Molinero, T. Willingness to Pay More to Stay at a Boutique Hotel with an Environmental Management System. A Preliminary Study in Spain. Sustainability 2019, 11, 5134. [CrossRef]

7. Martínez, P.; Herrero, Á.; Gómez-López, R. Corporate images and customer behavioral intentions in an environmentally certified context: Promoting environmental sustainability in the hospitality industry. Corp. Soc. Resp. Environ. Ma. 2019, 26, $1382-1391$. [CrossRef]

8. Eid, R.; Agag, G.; Shehawy, Y.M. Understanding Guests' Intention to Visit Green Hotels. J. Hosp. Tour. Res. 2021, 45, 494-528. [CrossRef]

9. Hu, X.; Danso, B.A.; Mensah, I.A.; Addai, M. Does Innovation Type Influence Firm Performance? A Dilemma of Star-Rated Hotels in Ghana. Sustainability 2020, 12, 9912. [CrossRef]

10. Wu, H.C.; Wei, C.F.; Tseng, L.Y.; Cheng, C.C. What drives green brand switching behavior? Mark. Intell. Plan. 2018, 36, 694-708. [CrossRef]

11. Robin, C.F.; Pedroche, M.S.C.; Astorga, P.S. Revisiting green practices in the hotel industry: A comparison between mature and emerging destinations. J. Clean. Prod. 2017, 140, 1415-1428. [CrossRef]

12. Martínez, P. Customer loyalty: Exploring its antecedents from a green marketing perspective. Int. J. Contemp. Hosp. Manag. 2015, 27, 896-917. [CrossRef]

13. Mercade Mele, P.; Molina Gomez, J.; Garay, L. To green or not to green: The influence of green marketing on consumer behaviour in the hotel industry. Sustainability 2019, 11, 4623. [CrossRef]

14. Khare, A. Consumers' susceptibility to interpersonal influence as a determining factor of ecologically conscious behaviour". Mark. Intell. Plan. 2014, 32, 2-20. [CrossRef]

15. Cohen, M.; Murphy, J. Sustainable Consumption: Environmental Policy and the Social Sciences. In Exploring Sustainable Consumption; Cohen, M., Murphy, J., Eds.; Elsevier Science Ltd.: Oxford, UK, 2001; pp. 225-240.

16. Chen, Y.S. The drivers of green brand equity: Green brand image, green satisfaction and green trust. J. Bus. Ethics 2010, 93, 307-319. [CrossRef] 
17. Polonsky, M.J. A stakeholder theory approach to designing environmental marketing strategy. J. Bus. Ind. Mark. 1995, 10, 29-46. [CrossRef]

18. Do Paco, A.M.F.; Raposo, M.L.B.; Leal Filho, W. Identifying the green consumer: A segmentation study. J. Target. Meas. Anal. Mark. 2009, 17, 17-25. [CrossRef]

19. Karyotakis, M.A.; Antonopoulos, N. Web Communication: A Content Analysis of Green Hosting Companies. Sustainability 2021, 13, 495. [CrossRef]

20. Aguilar, A. Marketing verde, una oportunidad para el cambio organizacional. Real. Y Reflexión 2016, 44, 93-104. [CrossRef]

21. Witek, L.; Kuźniar, W. Green Purchase Behavior: The Effectiveness of Sociodemographic Variables for Explaining Green Purchases in Emerging Market. Sustainability 2021, 13, 209. [CrossRef]

22. Ottman, J. The New Rules of Green Marketing: Strategies, Tools, and Inspiration for Sustainable Branding; Routledge: London, UK, 2011.

23. Bohdanowicz, P. European hoteliers' environmental attitudes: Greening the business. Cornell Hosp. Q. 2005, 46, 188-204. [CrossRef]

24. Pizam, A. Green hotels: A fad, ploy or fact of life? Int. J. Hosp. Manag. 2009, 28, 1-182. [CrossRef]

25. Green Hotels Association. What are green hotels? Available online: http://greenhotels.com/index.php (accessed on 10 December 2020).

26. Laroche, M.; Bergeron, J.; Barbaro-Forleo, G. Targeting consumers who are willing to pay more for environmentally friendly products. J. Consum. Mark. 2001, 18, 503-520. [CrossRef]

27. Cronin, J.J.; Smith, J.S.; Gleim, M.R.; Ramirez, E.; Martinez, J.D. Green marketing strategies: An examination of stakeholders and the opportunities they present. J. Acad. Mark. Sci. 2011, 39, 158-174. [CrossRef]

28. Foris, D.; Crihalmean, N.; Foris, T. Exploring the Environmental Practices in Hospitality through Booking Websites and Online Tourist Reviews. Sustainability 2020, 12, 282. [CrossRef]

29. Lavidge, R.J.; Steiner, G.A. A Model for Predictive Measurements of Advertising Effectiveness. J. Mark. 1961, 25, 59-62. [CrossRef]

30. Han, H.; Chen, C.; Lho, L.H.; Kim, H.; Yu, J. Green Hotels: Exploring the Drivers of Customer Approach Behaviors for Green Consumption. Sustainability 2020, 12, 9144. [CrossRef]

31. Ogilvy, D.; Navarro, F.I. Confesiones de un Publicitario; Oikos-Tau: Barcelona, Spain, 1967.

32. Aaker, D.A. Managing Brand Equity; Free Press: New York, NY, USA, 1991.

33. Herrera, D.; Quezada, G. Valor de Marca Verde y su Relación Con: Imagen de Marca Verde, Satisfacción Verde y Confianza Verde; Internet; Universidad de Chile_Facultad de Economía y Negocios: Santiago, Chile, 2011. Available online: http://repositorio.uchile.cl/ handle/2250/108096 (accessed on 23 October 2020).

34. Moise, M.S.; Gil-Saura, I.; Ruiz Molina, M.E. The importance of green practices for hotel guests: Does gender matter? Econ. Res. Ekon. Istraživanja 2021. [CrossRef]

35. Folse, J.A.G.; Netemeyer, R.G.; Burton, S. Spokescharacters. J. Advert. 2012, 41, 17-32. [CrossRef]

36. Schivinski, B.; Dabrowski, D. The effect of social media communication on consumer perceptions of brands. J. Mark. Commun. 2016, 22, 189-214. [CrossRef]

37. Han, H.; Eom, T.; Chung, H.; Lee, S.; Ryu, H.B.; Kim, W. Passenger repurchase behaviours in the green cruise line context: Exploring the role of quality, image, and physical environment. Sustainability 2019, 11, 1985. [CrossRef]

38. Moreira, A.; Silva, P.M.; Moutinho, M. The Effects of Brand Experiences on Quality, Satisfaction and Loyalty: An Empirical Study in the Telecommunications Multiple-play Service Market. Innovar 2017, 27, 23-38. [CrossRef]

39. Homburg, C.; Koschate, N.; Hoyer, W.D. Do satisfied customers really pay more? A study of the relationship between customer satisfaction and willingness to pay. J. Mark. 2005, 69, 84-96. [CrossRef]

40. Oliver, R.L. Whence consumer loyalty? J. Mark. 1999, 63 (Suppl. 4), 33-44. [CrossRef]

41. Assaker, G.; O'Connor, P.; El-Haddad, R. Examining an integrated model of green image, perceived quality, satisfaction, trust, and loyalty in upscale hotels. J. Hosp. Mark. Manag. 2020, 29, 934-955. [CrossRef]

42. Morgan, R.M.; Hunt, S.D. The commitment-trust theory of relationship marketing. J. Mark. 1994, 58, 20-38. [CrossRef]

43. Sarmiento-Guede, J.R.; Ferrao Filipe, A.J. La e-experiencia de marca a través de los medios sociales y su influencia en la e-calidad de la relación y la e-fidelización. Análisis empírico en los sitios web de viajes. Cuad. De Tur. 2019, 1, 351-380. [CrossRef]

44. Portillo, R.B.; de Esteban Curiel, J. Ecoturismo: Hacia Una Gestión Sostenible Moderna; Editorial Síntesis: Madrid, Spain, 2016.

45. Chuah, S.H.W.; El-Manstrly, D.; Tseng, M.L.; Ramayah, T. Sustaining customer engagement behavior through corporate social responsibility: The roles of environmental concern and green trust. J. Clean. Prod. 2020, 262. [CrossRef]

46. Feyers, S.; Stein, T.; Klizentyte, K. Bridging Worlds: Utilizing a Multi-Stakeholder Framework to Create Extension-Tourism Partnerships. Sustainability 2020, 12, 80. [CrossRef]

47. Flavián, C.; Guinalíu, M.E.; Torres, E. The influence of corporate image on consumer trust: A comparative analysis in traditional versus internet banking. Internet Res. 2005, 15, 447-470. [CrossRef]

48. Sarmiento-Guede, J.R. Marketing de Relaciones: Aproximación a las Relaciones Virtuales; Editorial Dykinson: Madrid, Spain, 2015.

49. Ibe-Enwo, G.; Igbudu, N.; Garanti, Z.; Popoola, T. Assessing the relevance of green banking practice on bank loyalty: The mediating effect of green image and bank trust. Sustainability 2019, 11, 4651. [CrossRef]

50. Chung, K.C. Green marketing orientation: Achieving sustainable development in green hotel management. J. Hosp. Mark. Manag. 2020, 29, 722-738. [CrossRef] 
51. Sarmiento Guede, J.R. La experiencia de la calidad de servicio online como antecedente de la satisfacción online: Estudio empírico en los sitios web de viajes. Investig. Turísticas 2017, 13, 30-53. [CrossRef]

52. Instituto de Estadística de España. Estancia Media, por Tipo de Alojamiento por Comunidad y Ciudades Autónomas. 2021. Available online: https: / / www.ine.es/jaxiT3/Tabla.htm?t=2940\&L=0 (accessed on 6 January 2021).

53. Hair, J.F., Jr.; Babin, B.J.; Krey, N. Covariance-based structural equation modeling in the Journal of Advertising: Review and recommendations. J. Advert. 2017, 46, 163-177. [CrossRef]

54. Fornell, C.; Larcker, D.F. Evaluating structural equation models with unobservable variables and measurement error. J. Mark. Res. 1981, 28, 39-50. [CrossRef]

55. Yan, H.; Chai, H. Consumers' Intentions towards Green Hotels in China: An Empirical Study Based on Extended Norm Activation Model. Sustainability 2021, 13, 2165. [CrossRef]

56. Ottman, J.A.; Stafford, E.R.; Hartman, C.L. Avoiding Green Marketing myopia: Ways to improve consumer appeal for environmentally preferable products. Environ. Sci. Policy Sustain. Dev. 2006, 48, 22-36. [CrossRef]

57. Fuller, D.A. Sustainable Marketing: Managerial-Ecological Issues; Sage Publications Inc.: Thousand Oaks, CA, USA, 1999. [CrossRef]

58. Calomarde, J.V. Marketing Ecológico; Pirámide: Madrid, Spain, 2000.

59. American Marketing Association. Definitions of Marketing. Available online: https://www.ama.org/the-definition-ofmarketing-what-is-marketing/ (accessed on 20 December 2020). 